\title{
Circumpolar Diatom Database (CDD): a new database for use in paleolimnology and limnology
}

\author{
Reinhard Pienitz $\cdot$ Luc Cournoyer
}

Received: 27 November 2015/ Accepted: 14 November 2016/Published online: 19 November 2016

(C) The Author(s) 2016. This article is published with open access at Springerlink.com

\begin{abstract}
The Circumpolar Diatom Database (CDD) is a new, open-access, online resource for the analysis of species distribution and abundance of diatoms in high-latitude, circumpolar regions. We provide a short description of the CDD design and its components and the data consultation methods and procedures, to familiarize potential users with the project and the database. In addition, opportunities for data exchange and input are described, to allow optimal application and expansion of the CDD by the user community, composed of paleolimnologists, limnologists and northern researchers in related disciplines.
\end{abstract}

Keywords Database $\cdot$ Diatoms $\cdot$ Circumpolar regions $\cdot$ Biogeography $\cdot$ Ecology $\cdot$ Paleoecology

\section{Aim and scope of CDD}

Maintaining water quality and availability has become an environmental priority of many governments, including the Government of Canada (Environment Canada 2013). Nevertheless, various components of global change will have significant, long-lasting

R. Pienitz $(\bowtie) \cdot$ L. Cournoyer

Aquatic Paleoecology Laboratory, Département de Géographie, Centre d'études nordiques, Université Laval, 2405 rue de la Terrasse, Québec, QC G1V 0A6, Canada e-mail: reinhard.pienitz@cen.ulaval.ca impacts on the availability, distribution and quality of surface waters. Adequate understanding of these impacts has yet to emerge, presenting challenges for development of the best adaptive strategies for water management at local, regional and global scales (International Joint Commission 2004). An effective approach for understanding the potential future trajectories of freshwater resources in the face of rapid and widespread environmental change is the application of paleolimnological methods, which use physical, chemical and biological indicators preserved in lake and river sediments to infer past ecosystem dynamics (Vincent 2009), and provide a historical perspective on present-day conditions. Of the many biological indicators of past environmental conditions that are used routinely in paleolimnology, diatoms (class Bacillariophyceae) are among the most useful.

The international paleolimnological research community generates large amounts of paleo-data that feed into knowledge-transfer opportunities, understanding of environmental processes, and policy decisions on water protection (Smol 2002). Very often, however, these data are not used to their full potential because they are not systematically managed or made readily accessible to stakeholders (Elger et al. 2014). So far, relatively few international paleolimnological efforts/ initiatives have made data available via online databases [e.g. Diatom Paleolimnology Data Cooperative (http://diatom.acnatsci.org/dpdc), Diatoms of the United States (http://westerndiatoms.colorado.edu), European Diatom Database (http://craticula.ncl.ac.uk/ 
Eddi/jsp/index.jsp)]. As a result, the field of paleolimnology still faces challenges in bridging the gap between fundamental research and applied management, conservation and restoration of aquatic resources (Kumagai and Vincent 2003; Saulnier-Talbot 2015). Consequently, there is an increasing expectation from the research community that close attention should be given to data management and archiving, as noted by the recent Coalition on Publishing Data in the Earth and Space Sciences "Statement of Commitment" (COPDESS 2015).

The Circumpolar Diatom Database (CDD) primarily serves to facilitate analysis of biogeographic patterns and define autecological information on diatom species found in the remote circumpolar region of the northern hemisphere, which remain poorly known. The CDD was initiated in 1995 in the Aquatic Paleoecology Laboratory (Centre d'études nordiques, Université Laval, Quebec City). Its main objective is to illustrate and interpret spatial and temporal changes in the distribution of diatoms in the northern circumpolar region, in relation to limnological, environmental and geographical characteristics. The specific objectives of this undertaking were to: (1) develop a database structure enhanced by a Geographic Information System (GIS) for easy consultation and visualization of limnological and paleolimnological data, (2) elaborate biogeographical classifications and patterns based on the presence and absence of specific diatoms in space and time, and (3) add to the knowledge of and specify environmental and ecological preferences of the main diatom genera and specific taxa encountered in high-latitude regions, thereby complementing existing diatom databases for temperate and Antarctic regions [e.g. Canadian Diatom Database, European Diatom Database, Antarctic Freshwater Diatoms). Our aim was to develop a multifunctional database like the CDD to provide user-friendly access to data, while offering advanced storage, management and sharing functionalities.

\section{Geographic coverage of CDD}

Many sites were sampled throughout the northern circumpolar region over the past 22 years, mostly as part of paleolimnological studies completed by members of the Aquatic Paleoecology Laboratory at Centre for Northern Studies (Centre d'études nordiques-
CEN), Université Laval (Quebec City, Canada). In the early stages of the development of the CDD, the limnological and biological data were incorporated into a database in the software program FilemakerPro ${ }^{\circ}$. At the time, the aim of this simple database was to archive and integrate the data gathered by laboratory members into an easy consultation tool. The more recent advances in computing programs and the development of powerful GIS now enable biogeographic research and archiving of a large amount of environmental and species data in the newly designed CDD.

Recent data acquisition and incorporation tripled the amount of information contained within this latest version of the CDD. It now contains 572 sampling sites, 4014 diatom taxa, 40,114 occurrence data, 15 datasets and more than 15,000 limnological (lake water chemistry and physics) entries. Its geographic range extends over eight areas of the circumpolar Arctic, distributed across three continents: North America, Europe and Asia. These areas include Alaska, Yukon, Northwest Territories, Nunavut, northern Quebec (Nunavik), Labrador, northern Sweden and Siberia (Taymyr Peninsula, Lena Delta, Pechora River). Most, but not all data are from studies published in the scientific literature, and are made freely available via the CDD.

\section{Structure and functioning of CDD}

The CDD is an online, open-access database of diatom and associated ecological and paleolimnological data relevant to the study of global change. It contains data on regional surface-sample calibration sets (diatom counts, water chemistry, inference models-transfer functions), sediment cores (diatom counts, chronological information, and diatom-inferred characteristics), and other types of samples.

Based on a relational database model, the CDD is also designed to accommodate sediment core data obtained through paleolimnological research. As a result, its data can easily be used for spatial analysis, cartographic representation in a GIS or publication over the Internet. The establishment of a web-based user interface (http://www.cen.ulaval.ca/cdd) with search modules allows exploration of CDD functions in a simple and precise manner. The data in the database are linked in such a way that access to all 


\section{Taxa search}

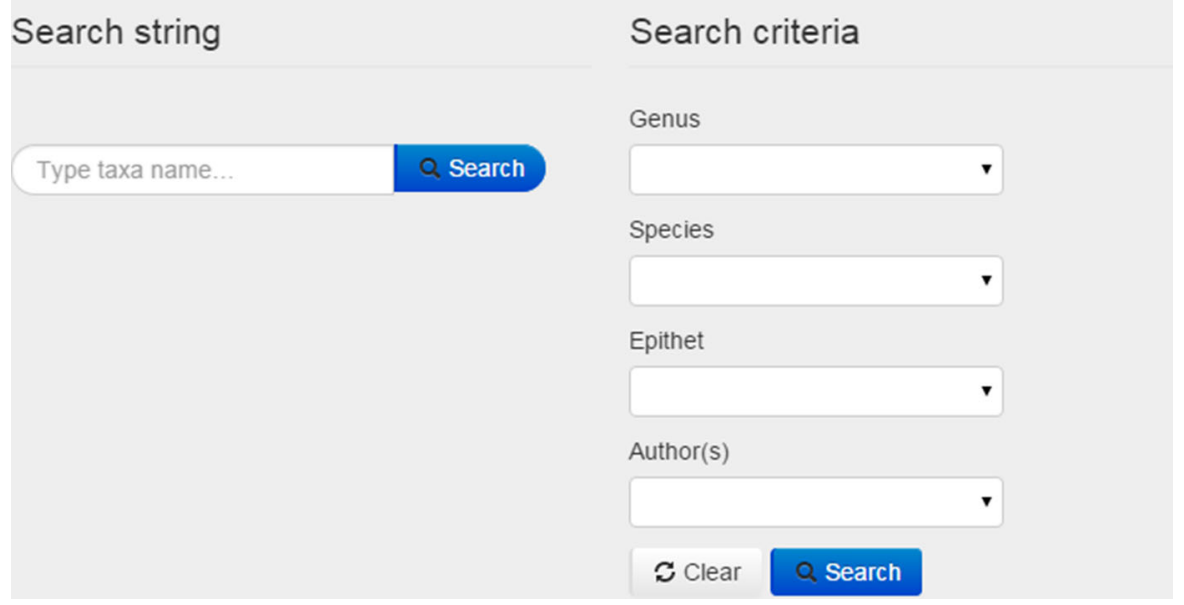

Fig. 1 Search tool for finding diatom taxa

\begin{tabular}{|c|c|c|c|c|}
\hline Taxon name & Dataset region & Lake code & Occur. (\%) & pH \\
\hline Achnanthes biasolettiana (Kützing) Grunow & $\begin{array}{l}\text { Yellowknife area, Northwest Territories, } \\
\text { Canada (YEL) }\end{array}$ & YEL003 & 0.26 & 8,7 \\
\hline Achnanthes biasolettiana (Kützing) Grunow & $\begin{array}{l}\text { Yellowknife area, Northwest Territories, } \\
\text { Canada (YEL) }\end{array}$ & YEL005 & 0.28 & 7,7 \\
\hline Achnanthes biasolettiana (Kützing) Grunow & $\begin{array}{l}\text { Yukon and Tuktoyaktuk Peninsula, } \\
\text { Northwest Territories, Canada (YUK) }\end{array}$ & YUK005 & 0.33 & 7,8 \\
\hline $\begin{array}{l}\text { Achnanthes biasolettiana var. subatomus } \\
\text { Lange-Bertalot }\end{array}$ & Northern Quebec (QUE) & QUE022 & 1.2 & 6,8 \\
\hline $\begin{array}{l}\text { Achnanthes biasolettiana var. subatomus } \\
\text { Lange-Bertalot }\end{array}$ & Northern Quebec (QUE) & QUE033 & 0.6 & 5,5 \\
\hline $\begin{array}{l}\text { Achnanthes biasolettiana var. subatomus } \\
\text { Lange-Bertalot }\end{array}$ & Northern Quebec (QUE) & QUE034 & 5 & 5,3 \\
\hline $\begin{array}{l}\text { Achnanthes biasolettiana var. subatomus } \\
\text { Lange-Bertalot }\end{array}$ & Northern Quebec (QUE) & QUE035 & 0.2 & 5,1 \\
\hline $\begin{array}{l}\text { Achnanthes biasolettiana var. subatomus } \\
\text { Lange-Bertalot }\end{array}$ & Northern Quebec (QUE) & QUE036 & 2.8 & 5,3 \\
\hline $\begin{array}{l}\text { Achnanthes biasolettiana var. subatomus } \\
\text { Lange-Bertalot }\end{array}$ & Northern Quebec (QUE) & QUE042 & 0.2 & 7 \\
\hline
\end{tabular}

Fig. 2 Example result set of taxa corresponding to search criteria. This list allows access to the taxon or dataset description

information relevant to each taxon, lake or dataset is straightforward and user-friendly.

The web interface is divided into three sections, allowing the user to search for data on (1) the biogeographic distribution of specific taxa, (2) datasets included in the database, and (3) contributors to the database. The first section allows an investigator to obtain a list of all taxa indexed in the CDD by indicating search criteria. One can choose the complete list or search for specific species and search for all occurrences of an individual taxon among all datasets (Fig. 1). The search can be by genus, species or subspecies (variety). From the result set, one can then access the taxon description, as well as the dataset 


\section{Amphipleura pellicula \\ Morphological group: Symmetrical biraphid Specific project notes:}

\section{Lake and dataset info Dataset detalis}

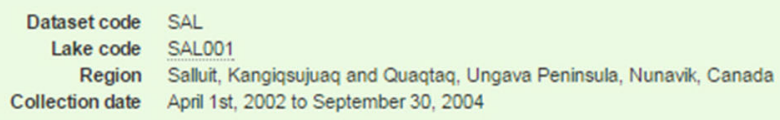

\section{Geographical locations}

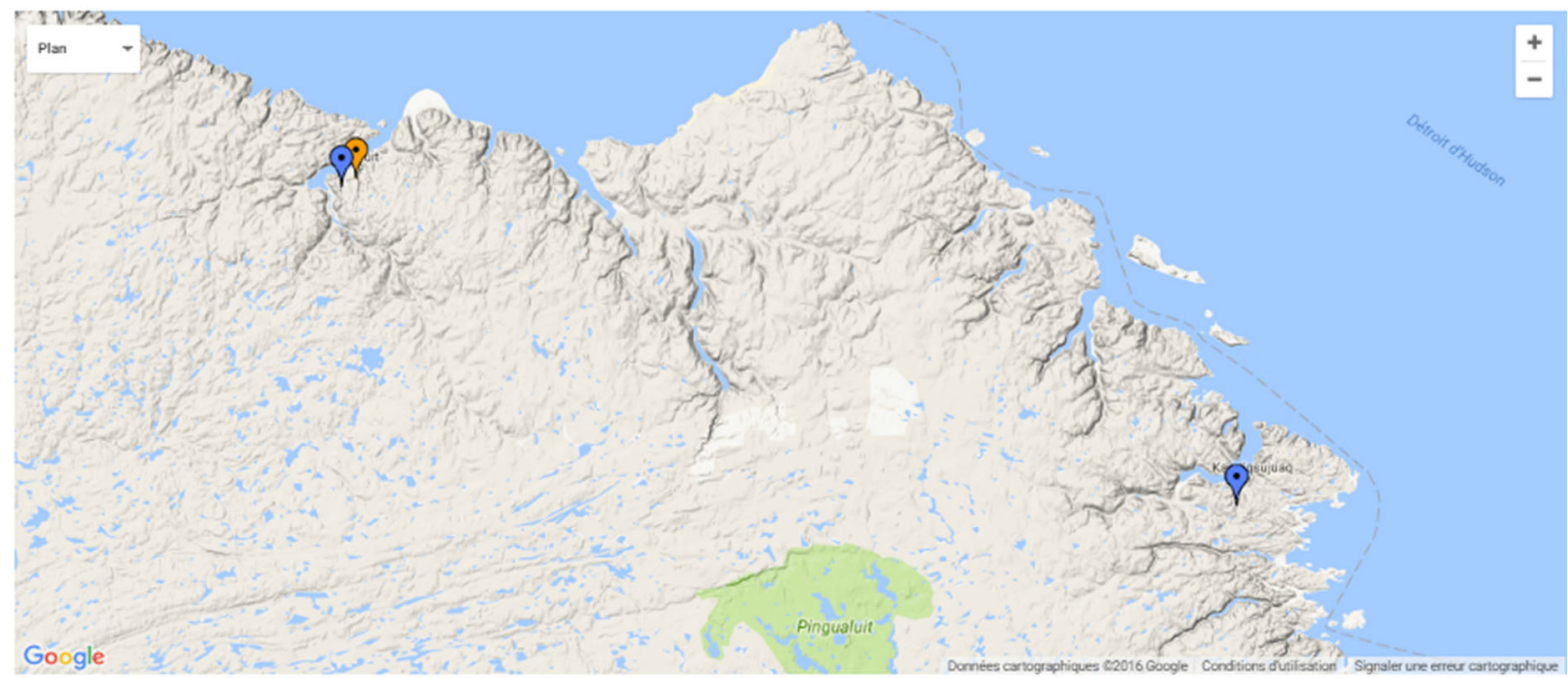

\section{Occurrence and environmental data}

Amphipleura pellicula, in lake SAL001

\begin{tabular}{|c|c|c|c|c|c|}
\hline & \multirow[t]{2}{*}{ Taxon occurrence } & & \multicolumn{3}{|c|}{ Environmental data } \\
\hline & & Change variable - & & & \\
\hline \multirow{2}{*}{ Core level $(\mathrm{cm})$} & \multirow{2}{*}{ Occurrence (\%) } & \multirow{2}{*}{$\begin{array}{c}\text { Undeterminated } \\
\text { taxa }(\%)\end{array}$} & Abbreviation & Parameter name & Value \\
\hline & & & COND & Conductivity & $0,07(\mathrm{US} / \mathrm{cm})$ \\
\hline $24 \cdot 24,5$ & 0.329 & & DO & Dissolved oxygen & $12,3(\mathrm{mg} / \mathrm{L})$ \\
\hline $26-26,5$ & 2.632 & & pH & Potential of hydrogen ion & 6,8 \\
\hline $28-28,5$ & 2.941 & & & & \\
\hline $30-30,5$ & 5.246 & & & & \\
\hline $32-32,5$ & 1.303 & & & & \\
\hline $34-34,5$ & 1.286 & & & & \\
\hline
\end{tabular}

Fig. 3 Taxon description, exemplified by Amphipleura pellicula 


\section{Salluit, Kangiqsujuaq and Quaqtaq, Ungava Peninsula, Nunavik, Canada

\author{
Dataset code SAL
}

Contact: Émilie Saulnier-Talbot, Reinhard Pienitz

Collection date: April 1st, 2002 to September 30, 2004

\section{Dataset info}

\author{
Research area \\ Longitude $-69.56^{\circ}$ to $-75.72^{\circ}$ \\ Latitude $60.86^{\circ}$ to $60.86^{\circ}$ \\ Publication \\ - 2007, Saulnier-Talbot, E., Leng, M.J. and Pienitz, P. \\ - 2007, Saulnier-Talbot, E.
}

\author{
Main publication summary \\ Saulnier-Talbot, E., Leng, M.J. and Pienitz, P. 2007. Recent climate and stable \\ isotopes in modern surface waters of northernmost Ungava Peninsula, Canada. \\ Canadian Joumal of Earth Sciences 44: 171-180 [DOI: 10.1139/E06-089]. \\ The isotope composition ( $d 18 \mathrm{O}$ and $\mathrm{dD}$ ) of surface waters was measured over a 26 . \\ month period near three localities situated along the northem coast of Ungava \\ Peninsula, Quebec, Canada. To characterize the present-day local hydrological \\ settings, the oxygen and hydrogen isotope ratios were measured from precipitation \\ and were compared to local and regional climate data. We show that the modem \\ surface waters contain information on climate and that this relationship is likely to be \\ transferred to biotic components within the lakes. These components, once \\ sedimented, are therefore likely to form an archive of climate change. The new data \\ presented here show the possibility of isotope paleoclimatic investigation based on \\ lake sediments in the northern coastal region of Ungava Peninsula.
}

\section{Environmental and physical data}

Salluit, Kangiqsujuaq and Quaqtaq, Ungava Peninsula, Nunavik, Canada (SAL dataset: 7 sampled lakes)

\begin{tabular}{|c|c|c|c|c|}
\hline Parameter (unit) & Result_AVG & Result_MAX & Result_MIN & N (samples) \\
\hline COND uS/cm & 0.08 & 0.23 & 0.02 & 6 \\
\hline$D O$ mg/L & 13.28 & 14 & 12.3 & 6 \\
\hline $\mathrm{pH}$ & 6.53 & 7.2 & 6 & 6 \\
\hline TEMP ${ }^{\circ} \mathrm{C}$ & 8.37 & 10.9 & 6.7 & 3 \\
\hline
\end{tabular}

Fig. 4 Example of dataset description

with the limnological data, taxon occurrence, water chemistry, environmental data, lake characteristics, etc. where the taxon was found (Figs. 2, 3).

The second section makes it possible to consult and access the list of datasets contained within the CDD. For each dataset, a brief description is supplied, along with the geographic coordinates of the study region, relevant publications in scientific journals and the limnological and environmental data (Fig. 4). For potential users of the CDD, zip files each containing a «Water chemistry» and an «Abundance» data file can be downloaded directly from the CDD website via the "Dataset" page using the "download data" function/button (http://www.cen.ulaval.ca/cdd/
DatasetList.aspx). Finally, the third section holds a list of contributors who supplied data to the respective datasets.

\section{Quality control of diatom taxonomy}

To ensure harmonization of diatom identifications among contributors (diatomists) to the CDD, and to improve comparisons between diatom studies and datasets, diatom inter-calibration and harmonization exercises were organized within a series of ArcticAntarctic Diatom Symposia and workshops (AADS) that were initiated in 1991 (Hamilton 1994). 


\section{Future developments and outlook}

Future development of the CDD will include the addition of a spatial representation and search engine of its contents to facilitate access to the data, in addition to increasing its visibility at an international scale and encouraging contributions. In the longer term, the CDD will be upgraded to accept data submission from external contributors via intranet for the easy upload of relevant data and metadata.

Furthermore, we will aim to develop a database structure enhanced by a GIS approach for easy consultation and visualization of limnological and paleolimnological data. Development of spatial representation of its contents facilitates access to the data, in addition to increasing its visibility at an international scale and encouraging contributions.

Finally, the data in the CDD will be published via Nordicana D, a formatted, online doi-referenced data report series, to facilitate the access and referencing of the data sets. This will also allow the recognition of individual researchers who have contributed to the database, while assuring wide dissemination of the information contained within the CDD.

\section{Conclusions}

The CDD was developed with the aim of offering researchers in the aquatic paleosciences and in diatom research a simple reference tool for easy acquisition of information on the spatial and temporal distribution and occurrence (biogeography) of diatom taxa from northern freshwater ecosystems and habitats. Beyond this, the CDD also serves as an information resource for limnologists, hydrologists, climate scientists and others interested in long-term aquatic ecosystem change and long-term data related to climate change and other global environmental issues.

The CDD aims to be an internationally recognized data acquisition reference for paleolimnologists, limnologists and diatomists. To ensure its success, interested members of the international scientific research community are encouraged to contribute to the project by sharing their data on diatom distribution and abundance resulting from research in the circumpolar regions, including diatom data from sediment cores and surface deposits. Contributions to the CDD will result in the expansion of knowledge on the autecology, spatial and temporal distributions of diatoms.

The Aquatic Paleoecology Laboratory will be grateful to receive and formally acknowledge your data contributions. Please contact us at cdd@cen.ulaval.ca, Laboratoire de Paléoécologie Aquatique, Centre d'études nordiques (CEN), Pavillon Abitibi-Price, 2405 rue de la Terrasse, Université Laval, Québec City (Canada), G1V 0A6 (Phone: 1-418-656-2131 +7006). We cordially invite you to cooperate in this effort, as the success of the CDD will largely depend on the voluntary submissions of the diatom paleoecology community!

Acknowledgements We thank the following individuals and organizations for their help with development of this database: Stéphane Campeau, Martin Sirois, NSERC Discovery and Accelerator grants awarded to R. Pienitz and additional financial support obtained through the Centre for Northern Studies (CEN-Centre d'études nordiques). We thank Dr. Émilie Saulnier-Talbot and Dr. Warwick Vincent for helpful comments on the final version of the manuscript (1700432008RGPIN).

Open Access This article is distributed under the terms of the Creative Commons Attribution 4.0 International License (http:// creativecommons.org/licenses/by/4.0/), which permits unrestricted use, distribution, and reproduction in any medium, provided you give appropriate credit to the original author(s) and the source, provide a link to the Creative Commons license, and indicate if changes were made.

\section{References}

Antarctic Freshwater Diatoms. http://huey.colorado.edu/diatoms

Canadian Diatom Database. http://open.canada.ca/en/ckan/ canadian-diatom-database

COPDESS (2015) Statement of commitment from earth and space science publishers and data facilities. [cited August 25, 2015]. http://www.copdess.org/statement-of-commitment/

Diatom Paleolimnology Data Cooperative. http://diatom.acnat sci.org/dpdc

Diatoms of the United States. http://westerndiatoms.colorado. edu

European Diatom Database. http://craticula.ncl.ac.uk/Eddi/jsp/ index.jsp

Elger K, Barnard C, Vincent WF (2014) Theme 11 - Knowledge capture and data management. In: Topp-Jørgensen E (ed) INTERACT Management planning for arctic and northern alpine research stations- examples of good practices. Aarhus University, DCE-Danish Centre for Environment and Energy, Aarhus, pp 233-254

Environment Canada (2013) Planning for a sustainable future: a federal sustainable development strategy for Canada 2013-2016. [cited August 25, 2015]. https://www.ec.gc.ca/ dd-sd/default.asp?lang=en\&n=AD293762-1 
Hamilton P (1994) Proceedings of the Fourth Arctic-Antarctic Diatom Symposium (Workshop). Canadian Museum of Nature, Ottawa, Ontario. September 18-21, 1993. Can Tech Rep Fish Aquat Sci No. 1957, p 139

International Joint Commission (2004) 12th Biennial report on great lakes water quality: the challenge to restore and protect the largest body of fresh water in the world. International Joint Commission, Oakbrook Terrace, Illinois

Kumagai M, Vincent WF (2003) Freshwater management: global versus local perspectives. Springer, Japan, p 233
Saulnier-Talbot É (2015) Overcoming the disconnect: Are paleolimnologists doing enough to make their science accessible to aquatic managers and conservationists? Front Ecol Evol 3:32. doi:10.3389/fevo.2015.00032

Smol JP (2002) Pollution of lakes and rivers: a paleoenvironmental perspective. Oxford University Press Inc., New York, p 280

Vincent WF (2009) Effects of climate change on lakes. In: Likens G (ed) Encyclopedia of inland waters. Elsevier, Oxford, pp 55-60 